\section{AAOUJ}

11,2

\title{
Profiling information-seeking behaviour of distance learning students in Wawasan Open University
}

\author{
Vighnarajah \\ School of Education, Languages and Communications, \\ Wawasan Open University, George Town, Malaysia, and \\ Farzanah Ali Hassan, Norhasni Abd Aziz and Ooi Siew Lee \\ Wawasan Open University, George Town, Malaysia
}

\begin{abstract}
Purpose - Wawasan Open University Library undertook a survey study, based on the Wilson's revised model of information behaviour (1999), to profile information-seeking behaviour of their distance students in using library resources in their research and learning activities. The paper aims to discuss these issues.

Design/methodology/approach - Using random sampling method, samples were selected to ensure proper representation of the population across four schools of studies and five regional centres. A total of 550 questionnaires were sent to undergraduate and postgraduate students, and 435 completed questionnaires were returned with a success response rate of 79 per cent.

Findings - Findings indicated significant differences between undergraduate and postgraduate students in using the university's MyDigital Library and physical library for their information needs. Findings also indicated significant difference between first-year and post-first-year students in using internet search engines as part of their information-seeking process.

Practical implications - Students improving on their information-seeking behaviour in the learning and research work paved way for them to better experience university vivacity and not isolate themselves from distance learning.

Originality/value - This paper acknowledges the importance of promoting good informationseeking behaviour among distance learners in the scholarship of learning and research work. The paper also amplifies the important role library plays in minimizing students' sense of isolation in university learning experience.
\end{abstract}

Keywords Information needs, Information-seeking behaviour, Distance learning, Wawasan Open University, Wilson's model of information behaviour

Paper type Research paper

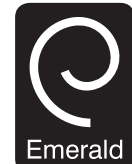

Asian Association of Open Universities Journal Vol. 11 No. 2, 2016 pp. $122-135$ Emerald Group Publishing Limited 1858-3431

DOI 10.1108/AAOUJ-09-2016-0026
(C) Vighnarajah, Farzanah, A.H., Norhasni, A.A. and Ooi, S.L. Published in the Asian Association of Open Universities. This article is published under the Creative Commons Attribution (CC BY 4.0) licence. Anyone may reproduce, distribute, translate and create derivative works of this article (for both commercial and non-commercial purposes), subject to full attribution to the original publication and authors. The full terms of this licence may be seen at: http://creative commons.org/licences/by/4.0/legalcode

The researchers would like to acknowledge and express gratitude to the Institute for Research and Innovations (IRI), Wawasan Open University, for funding this research. The researchers are also deeply grateful to Tan Sri Professor Emeritus Gajaraj and the Director of Library Services, Pn Kamsiah Mohd Ali, who have given valuable feedback and have continued to provide leadership. 


\section{Introduction}

The emergence and development of technology-aided distance education is a relatively new approach in the Malaysian educational landscape. With the recent exponential technological development in educational practices, a growing number of institutions have attempted to service distance education programmes via various modes, some favouring more face-to-face contact hours while others take a liking for engagement in the online learning environment. Regardless on these modes of delivery, what is certain is the need for students to be technologically literate for them to successfully savour the university learning experience.

Wawasan Open University offered the first suite of 11 programmes in 2007 and is now offering a suite of 47 programmes. Wawasan Open University is one of the three full-fledged distance learning institutions in Malaysia that deliver distance learning programmes with a heavier focus on engagement in online learning environment. While this mode is not uncommon in many of the full-fledged and recognized distance learning institutions such as IGNOU and Athabasca University, it is imperative to pay consideration to the competency of students in engaging and interacting in the online learning environment, particularly in the process of information search and effectively utilizing the said information for learning and research work.

This responsibility is shouldered by the Tun Dr Lim Chong Eu Library of Wawasan Open University, which adheres to the Guidelines for Distance Learning Library Services; (Distance Learning Section Guidelines Committee, 2004, p. 607):

Members of the distance learning community, including those with disabilities, must therefore be provided effective and appropriate library services and resources, which may differ from, but must be equivalent to those provided for students and faculty in traditional campus settings.

Based on this philosophy of the Bill of Rights for the Distance Learning Community, the Standard for Access for Achievement of Superior Academic Skills requires the library of distance learning institutions, despite circumstances of geographical distance, limited face-to-face contact hours and other aspects relevant to the provisions of distance learning, to provide services and resources equivalent to conventional institutions (American Library Association, 2008). This is a standard of practice for library services that is often undervalued in some distance learning institutions, which ultimately leads to the common perception that the library is no more than an avenue for collection of books and resources, which is certainly not the case.

The ensuing discussion attempts to highlight the significant role of the library in distance learning institutions, specifically by investigating the profiling of informationseeking behaviour of distance learners in Wawasan Open University.

\section{Information-seeking behaviour and its role in the scholarship of learning and research}

Information-seeking behaviour refers to the process of seeking, collecting, analysing and utilizing information in a meaningful manner (Byström and Hansen, 2005), and this is an iterative process until the user acquires the intended information. Figure 1 illustrates Wilson's (1999) information-seeking model that is commonly used in demonstrating the steps in information-seeking behaviour.

While this model was developed during the infancy of distance learning and online learning, the model still acts as a robust framework to explore and assess both off-line and online information-seeking behaviours. The fundamental concepts that form the basis of this model are the components information use, information need and information 


\section{AAOUJ}

11,2

\section{4}

Figure 1.

Wilson's information behaviour model

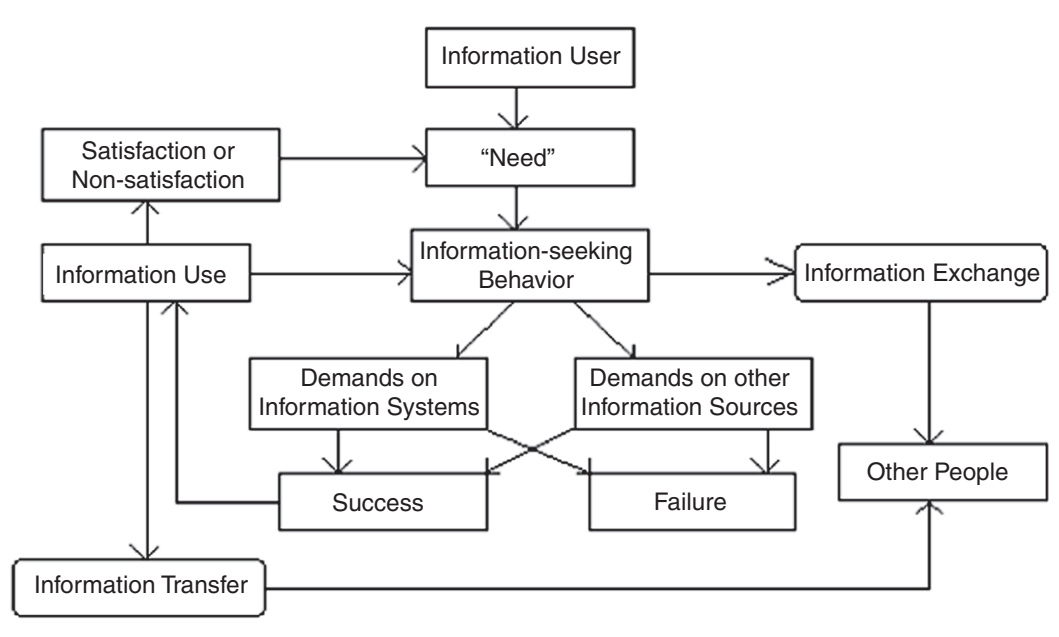

exchange. Over the years, these features remain relevant and invariably describe the interrelationship among concepts of information-seeking behaviour of users (Wilson, 2006).

In fact, the published article which presented the Wilson's model inspired the development of information research and has been cited over 100 times in book chapters, reports, conference proceedings and ISI journal databases, including Journal of the American Society for Information Science and Technology, Journal of Documentation, Information Processing and Management and Library and Information Science Research (Bawden, 2006, p. 672). This suggests continued interest in the works of Wilson's model.

Wilson (1999, p. 249) describes information seeking as "activities a person may engage in when identifying their own needs for information, searching for such information in any way, and using or transferring that information". In the context of the study, this description of information-seeking behaviour translates to distance learners' active and purposeful information seeking that results from the need to complete course assignments, preparation for tutorial discussion, engagement in workshops and engagement in research work.

While information seeking can be achieved without (physical collection of resources) or with (digital collection of resources) computing assistance, the latter is becoming more significantly associated with the internet and ubiquitous computing. For instance, there is this growing social aspect of information seeking that Shah et al. (2014, p. 23) elucidate as "current work [information seeking] coincides with a combination of new technologies, such as Web 2.0 and social media/networking tools, and changes in human behaviour, including people's increasing tendency to quickly and ubiquitously share and connect with others through new interfaces and devices". They further argued that it is this confluence of modes of seeking and sharing information that sparked the need to better comprehend information-seeking behaviour in this changing trend of technological development. Although a substantial body of literature exists expounding both theoretical and empirical findings on profiling information-seeking behaviour in a variety of contexts, still there is an enduring concern in observing such behaviours that correlate with the changing online environment in distance education - and this begs the question, "What are some of the challenges that distance learners face in information search and information utilization in the age of Internet data mining?"

Looking across both dimensions of emerging technological developments and expansion of distance education, it becomes clear that information-seeking behaviour is 
an individualistic process, and invariably, the information needs for every individual is different depending on the necessities for learning and research work. Moreover, students being digital natives of the internet age do not warrant possessing effective information-searching skills (Brown et al., 2003) or being "functionally information illiterate" (Majka, 2001), asserting the fact that "techno-savvy is not synonymous with information-literate" (Alman et al., 2012).

Loh (2013, p. 250) argues "[w]ith the overconfidence of the information skills, students are able to fulfil simple information needs, searching information to answer simple question that exhibits only surface learning. However, they are unable to explore deeper concepts or determine if they have really reduced uncertainty successfully".

Further to this, Dubicki (2010) also agreed that students are often confused and frustrated despite having the convenience of access to the internet. This is likely due to students' lack of knowledge and incompetency in evaluating information available on the internet in terms of relevance, accuracy and/or authority (Williams et al., 2008).

All these contentions only reinforce the fact that despite having ubiquitous access to the internet, students still need guidance to improve on their information-seeking skills (Lahlafi et al., 2012). Later studies have also highlighted that poor information search also causes students, especially distance learners, to develop a sense of isolation from the learning process, as well as from the university experience in general (Vighnarajah and Santhiram, 2014). Recognizing this key importance, the mandate falls onto the library to cultivate effective information-seeking behaviour among students, and this measure has initiated the library to take a shift to acknowledging the presence of increasingly complex information systems, among others, online repositories, e-resources, and electronic information sources (Devi and Dlamini, 2014; Head, 2013; Kadli and Kumbar, 2013; Kumar, 2013). In view of the aforementioned, the ensuing discussion attempts to study information-seeking behaviour of distance learners in Wawasan Open University, one of the premier distance learning institutions in Malaysia.

\section{Research objectives}

The primary aim of this study was to explore and profile information-seeking behaviour among distance learning students in Wawasan Open University. In the context of this study, information-seeking behaviour refers to both the process of information search as well as effective utilization of information obtained from the information search process.

The following objectives were developed, based on relevant literature governing information-seeking behaviour in distance learning, to guide the direction of the study:

(1) to identify the problems faced in information search among distance learning students in Wawasan Open University;

(2) to identify the problems faced in effective utilization of information among distance learning students in Wawasan Open University; and

(3) to examine the relationship between problems faced in information search and effective utilization of information.

\section{Methodology}

This study adopted the survey research design for several reasons. First, the survey research allowed the researchers to obtain the students' perceptions and practice in seeking information and utilizing the said information for learning and research activities across different schools, i.e., School of Business Administration, School of Science and 
AAOUJ

11,2

126
Technology, School of Foundation and Liberal Studies and School of Education, Languages and Communications. Second, this measure was particularly important considering the university has regional centres in five different states, namely, Kuala Lumpur, Penang, Ipoh, Johor Bahru and Kuching. These regional centres act as a student recruitment centre, and they provide the provisions of tutorial rooms, libraries and other relevant academic and operational facilities. Finally, this survey measure allowed for quantitative analysis that highlights statistical significance for relevant extrapolation of research findings, especially in the area of information management in distance learning.

The population of the study involved distance learners from the five regional centres that provide courses serviced by the four Schools. At this juncture, it must be noted that this is a preliminary study executed in relation to a larger funded research that also attempts to study information-seeking behaviour of distance learners in Wawasan Open University. This preliminary study aims to gauge the challenges faced in survey administration among distance learners in the university. One of the major challenges faced in gathering data in distance learning institutions was chances of low response rate due to the nature of distance learning mode. In the context of this study, tutorial attendance is optional and hence no obligatory measures are taken on the more commonly practice of 80 per cent attendance rate in conventional universities.

Based on the population across four schools of studies and five regional centres, a random sample of size of 550 respondents was decided. This figure satiated Krejcie and Morgan's (1970) requirement of randomly chosen sample size where the sample proportion will be within \pm 0.05 of the population proportion with a 95 per cent level of confidence. Without prejudice on any particular programme of study or preference of regional centre, 110 questionnaires were distributed to each regional centre for data collection purposes.

With advice sought from the respective regional centres on active average attendance rate for the tutorial weekends, the questionnaires were couriered to the respective regional centres to be administered accordingly to the tutorial classes identified by the researchers. In the sampling process, emphasis was also placed on avoiding data duplicates from students who attend both the first and second tutorial weekends. This particular emphasis on data duplication also drew attention to the fact that response to the administered survey was not course dependent but should focus on their (student's) overall information-seeking behaviour. Relevant concerns were highlighted to the staff at the respective regional centres that assisted in the administration of the survey.

During the administration process, clear instructions were given, and students were assured on the anonymity of their response to the survey instrument. The survey instrument was developed based on literature governing information-seeking behaviour among distance learners (Liu and Zheng, 2004) and completed with the researchers' experience in the field.

Prior to the administration process, the survey instrument was tested for face validity, content validity and construct validity by three experts in the field. One expert was a professor who provided constructive comments to the psychometric design of the items and ensured the proper context of the items to the distance learning. The other two experts were an associate professor and head of library services who both addressed expertise in the field of information-seeking behaviour in complex information systems such as online repositories, electronic information sources, OPAC and other relevant information databases. In general, these experts provided comments to improve the comprehensibility of the items and relevance of the items to reflect appropriate information-seeking behaviour. The reliability of the instrument was also satisfactory, yielding Cronbach's $\alpha$ value of 0.810 . 
The instrument was divided into three major sections. The first section aimed to elicit respondents' demographic information like age, gender, entry qualification, etc. The second section aimed to elicit respondents' use of library services such as frequency of access to library services, satisfaction regarding information resources, extent of use of internet search engines, etc. The third section aimed to elicit respondents' information search such as types of online information needs, problems faced in information search, problems faced in effectively utilizing information, etc. In general, items were presented on two types of scales: one where respondents had to check the boxes (more than one) to items that were relevant to them and the other responding to a five-point Likert scale ranging from "never" (1) to "always" (5).

\section{Results and findings}

Findings of the study drew attention to statistical data imperative to profile information-seeking behaviour among distance learners in Wawasan Open University. Findings of this study also bear importance to distance learners in other distance learning institutions that share similar parameters to Wawasan Open University.

From the total of 550 questionnaires administered, 435 completed questionnaires were returned accounting for a success response rate of 79 per cent. Table I presents the demographic findings of the 435 respondents. Based on the figures presented, 43.2 per cent $(n=188)$ of the respondents were male students whereas 56.8 per cent $(n=247)$ were female students. Almost half $(51.5$ per cent, $n=224)$ of the respondents were between the ages of 21 and 29 years while 30 per cent of the respondents $(n=130)$ were between the ages of 30 and 39 years. The remaining respondents were between the ages of 40 and 49 years and above 50 years, respectively. For the student status, a vast majority (76.8 per cent, $n=334$ ) of the respondents were undergraduate students whereas rest (23.2 per cent, $n=101$ ) of them were postgraduate students. Also, the majority (66.7 per cent, $n=290$ ) of the respondents had more than one year of learning experience.

In the ensuing discussion, findings of the study are presented in accordance to the research objectives of the study to facilitate comprehension.

Research objective 1: to identify the problems faced in information search among distance learning students in Wawasan Open University.

\begin{tabular}{|c|c|c|c|}
\hline Variable & Frequency & Percentage & \\
\hline $\begin{array}{l}\text { Gender } \\
\text { Male } \\
\text { Female }\end{array}$ & $\begin{array}{l}188 \\
247\end{array}$ & $\begin{array}{l}43.2 \\
56.8\end{array}$ & \\
\hline $\begin{array}{l}\text { Age } \\
21-29 \text { years } \\
30-39 \text { years } \\
40-49 \text { years } \\
\text { Above } 50 \text { years }\end{array}$ & $\begin{array}{r}224 \\
130 \\
63 \\
18\end{array}$ & $\begin{array}{r}51.5 \\
29.9 \\
14.5 \\
4.1\end{array}$ & \\
\hline $\begin{array}{l}\text { Student status } \\
\text { Undergraduate } \\
\text { Postgraduate }\end{array}$ & $\begin{array}{l}334 \\
101\end{array}$ & $\begin{array}{l}76.8 \\
23.2\end{array}$ & \\
\hline $\begin{array}{l}\text { Year of study } \\
\text { One year } \\
\text { Above one year }\end{array}$ & $\begin{array}{l}145 \\
290\end{array}$ & $\begin{array}{l}33.3 \\
66.7\end{array}$ & $\begin{array}{r}\text { Table I. } \\
\text { Demographic } \\
\text { findings }\end{array}$ \\
\hline
\end{tabular}


AAOUJ 11,2

128

Figure 2.

Problems faced by distance learners in their informationseeking process
There were seven major problems that distance learners experience in their information-seeking process. Figure 2 illustrates the problems faced by distance learners in their information-seeking process. The most significant problem they face is the inability to determine the appropriateness of the information they obtained (22 per cent). While this is not an uncommon concern among distance learners, findings do seem to imply that this particular problem leads to other relevant problems, mainly, not being able to locate information (19 per cent) and considering that information are outdated (14 per cent). The other concern that must be noted in this finding is how distance learners are not aware that relevant information is available in the library, whether in the form of hard copies or digital copies (12 per cent).

Given the vested interest in profiling information-seeking behaviour of distance learners, further analysis was conducted to examine their awareness of searching for information using the provisions of both MyDigital Library database and internet search engines. Referring to Figure 3, descriptive results clearly indicate that students, in their scholarly learning and research work, require guidance in searching for
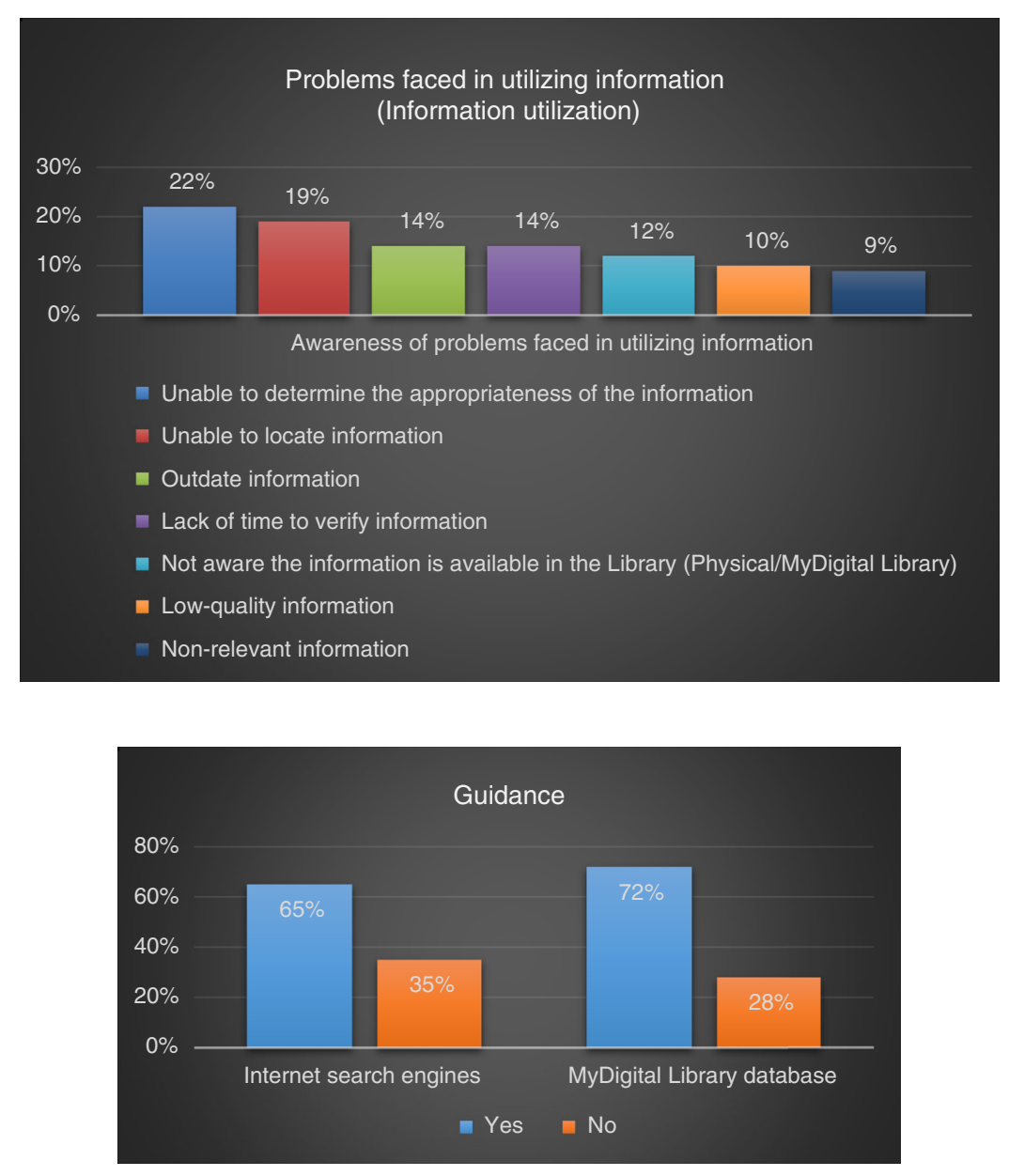

Figure 3.

Percentage of respondents who required guidance with online information search 
information using MyDigital Library database and internet search engines such as Google and Yahoo.

An independent sample $t$-test was used to statistically compare differences between undergraduate and postgraduate students in using digital library as their major source of information search in their learning and research work. Referring to Table II, the results indicate that there exists a significant difference $(t=3.415, p<0.01)$ in the scores between undergraduate students $(M=0.20, \mathrm{SD}=0.403)$ and postgraduate students $(M=0.39, \mathrm{SD}=0.489)$ in using MyDigital Library. Results also indicate a significant difference $(t=3.234, p<0.01)$ in the scores between undergraduate students $(M=0.18, \mathrm{SD}=0.271)$ and postgraduate students $(M=0.29, \mathrm{SD}=0.326)$ in using the physical library.

While the results did not reveal any significant differences between undergraduate and postgraduate students in using internet search engines for their learning and research work, results did indicate significant differences $(t=2.097, p<0.05)$ between first-year students $(M=0.81, \mathrm{SD}=0.396)$ and post-first-year students $(M=0.89$, $\mathrm{SD}=0.318$ ) in using internet search engines. In other words, post-first-year students are more likely to refer to internet search engines for information compared to the firstyear students (Table III).

Research objective 2: to identify the problems faced in effective utilization of information among distance learners in Wawasan Open University.

There were eight major problems that distance learners experienced in effectively utilizing information they obtained from the information search process. Refer to Figure 4.

The critical concern here is that distance learners were uncertain on how to integrate information into their assignments and research work (21 per cent). This is closely followed with the uncertainty on how to cite information (17 per cent), lack of local context in the information (15 per cent), poor use of information leads to high Turnitin similarity index (15 per cent) and uncertain over the quality of information obtained (14 per cent). Poor employment of these essential skills will surely impede any distance learner from progressing in the scholarship of learning and research.

\begin{tabular}{llllllll}
\hline Dependent variable $(Y)$ & Independent variable $(X)$ & $n$ & Mean & SD & SE mean & $t$ & Sig. \\
\hline MyDigital Library & Student status & & & & & & \\
& $\quad$ Undergraduate & 334 & 0.20 & 0.403 & 0.022 & 3.415 & $0.001^{* *}$ \\
& $\quad$ Postgraduate & 101 & 0.39 & 0.489 & 0.049 & & \\
Physical library & Student status & & & & & & \\
& $\quad$ Undergraduate & 334 & 0.18 & 0.271 & 0.0149 & 3.234 & $0.001^{* *}$ \\
& Postgraduate & 101 & 0.29 & 0.326 & 0.0325 & &
\end{tabular}

Note: ${ }^{* *} p<0.01$

Wawasan Open

University

129

\begin{tabular}{|c|c|c|c|c|c|c|c|c|}
\hline Dependent variable $(Y)$ & Independent variable $(X)$ & $n$ & Mean & $\mathrm{SD}$ & SE Mean & $t$ & Sig. & \\
\hline Internet search engines & $\begin{array}{l}\text { Year of study } \\
\text { First year } \\
\text { Post-first year }\end{array}$ & $\begin{array}{l}145 \\
290\end{array}$ & $\begin{array}{l}0.81 \\
0.89\end{array}$ & $\begin{array}{l}0.396 \\
0.318\end{array}$ & $\begin{array}{l}0.033 \\
0.019\end{array}$ & 2.097 & $0.05^{*}$ & $\begin{array}{r}\text { Table III. } \\
\text { Year of study } \\
\text { findings on internet }\end{array}$ \\
\hline Note: $* p<0.05$ & & & & & & & & search engines \\
\hline
\end{tabular}




\section{AAOUJ 11,2}

130

Figure 4.

Problems faced in effective utilization of information

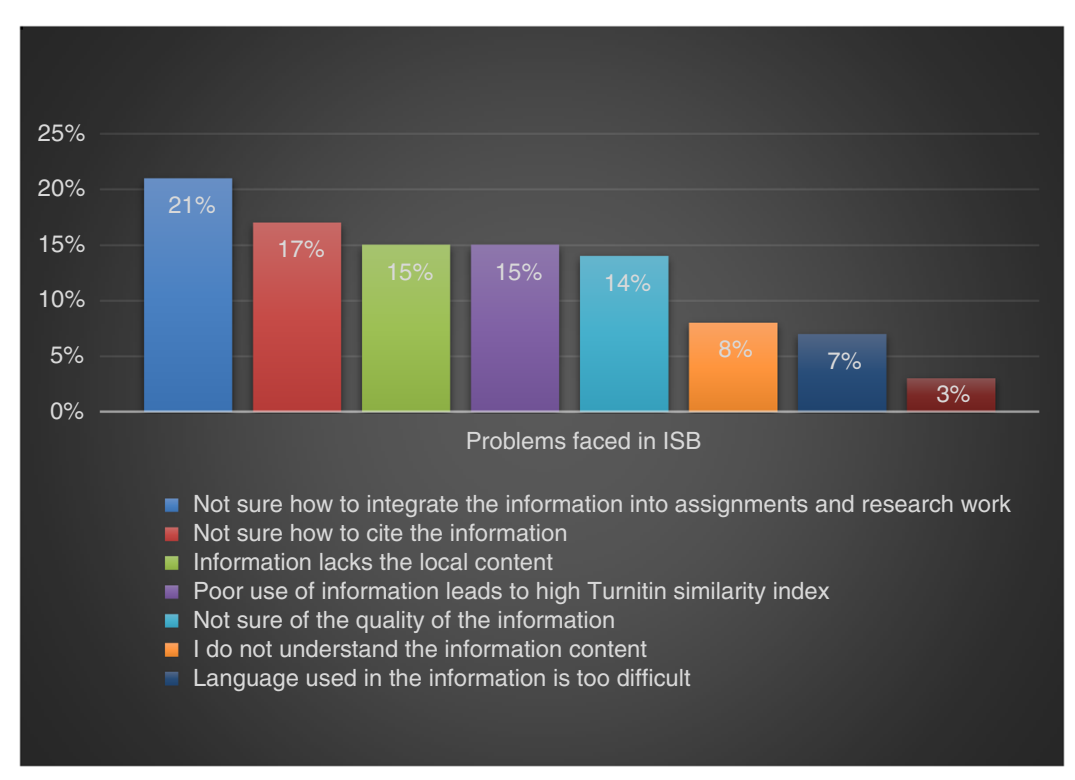

Further inferential analysis on these results revealed some interesting findings that necessitate relevant stakeholders, Library Support and Academics among others, to provide informative support in the relevant areas of concern. Referring to Table I, an independent sample $t$-test was used to statistically compare differences between undergraduate and postgraduate students in their understanding of information content. Results revealed that there exist a significant difference $(t=2.364, p<0.05)$ in the scores between undergraduate students $(M=0.16, \mathrm{SD}=0.366)$ and postgraduate students $(M=0.08, \mathrm{SD}=0.271)$. In other words, undergraduate students face more problems in understanding the content of the information they obtained compared to postgraduate students (Table IV).

In addition, independent sample $t$-test was used to statistically compare differences between years of study (first year vs post-first year) in their understanding of the language used in the information. Results revealed that there exists a significant difference $(t=1.702, p<0.05)$ in the scores for first-year student $(M=0.17, \mathrm{SD}=0.379)$ and post-first-year students $(M=0.11, \mathrm{SD}=0.314)$. Significant differences $(t=2.017$, $p<0.05)$ in mean were also obtained for first-year $(M=0.37, \mathrm{SD}=0.483)$ and post-firstyear students $(M=0.27, \mathrm{SD}=0.444)$ in properly citing information they obtained from the search process (Table V).

Table IV.

Student status

findings on comprehension of information content

\begin{tabular}{lllllllll}
\hline & $\begin{array}{l}\text { Independent } \\
\text { variable }(X)\end{array}$ & $n$ & Mean & SD & $\begin{array}{c}\text { SE } \\
\text { mean }\end{array}$ & $t$ & Sig. \\
\hline $\begin{array}{l}\text { Dependent variable }(Y) \\
\text { I do not understand the information }\end{array}$ & $\begin{array}{l}\text { Student status } \\
\text { content }\end{array}$ & & & & & & & \\
& $\begin{array}{l}\text { Undergraduate } \\
\text { Postgraduate }\end{array}$ & 101 & 0.08 & 0.271 & 0.027 & &
\end{tabular}

Note: ${ }^{* *} p<0.01$ 
Research objective 3: to examine the relationship between problems faced in information search and effective utilization of information.

A simple linear regression analysis was used to examine the relationship between problems faced in information search process and effective utilization of information. A positive correlation was found between both variables $(\beta=0.565, p<0.001)$. The results indicate that problems faced in information search process significantly predicts effective utilization of information, with 32 per cent prediction of the variance $(F(1,433)=202.619, p<0.01)($ Table VI)

\section{Discussion and implications}

The aim of this study was to explore and profile information-seeking behaviour among distance learners in Wawasan Open University. The operational definition of information-seeking behaviour refers to both the process of information search as well as effective utilization of information obtained from the information search process. Directed by this aim, specific objectives included identifying the problems faced in the information search process, problems faced in effective utilization of information and finally examining the relationship between these two factors.

Several implications were drawn from the findings of the study which address significant importance to the understanding of information-search behaviour of distance learners in Wawasan Open University. These implications also possess the potential to be extrapolated to other context of information-seeking behaviour of distance learners that shares similar parameters with this study. Findings of the study provide statistical evidence to the convictions that distance learners are not familiar with information-seeking processes and the subsequent process of effective utilization of information. In addition, findings have also revealed that unfamiliarity with information-search process mostly affects either undergraduate learners or first-year distance learners.

While this finding may have been somewhat anticipated, what is enlightening is that poor information-search behaviour can lead to distance learners to develop a sense of

\begin{tabular}{llllllllll}
\hline & $\begin{array}{l}\text { Independent } \\
\text { variable }(X))\end{array}$ & $n$ & Mean & SD & $\begin{array}{c}\text { SE } \\
\text { mean }\end{array}$ & $t$ & Sig. \\
\hline Dependent variable $(Y)$ & $\begin{array}{l}\text { Year of study } \\
\text { First year }\end{array}$ & 145 & 0.17 & 0.379 & 0.031 & 1.702 & $0.05^{*}$ \\
$\begin{array}{l}\text { Language used in the information is } \\
\text { too difficult }\end{array}$ & $\begin{array}{l}\text { Post-first year } \\
\text { Not sure on how to cite the information }\end{array}$ & 290 & 0.11 & 0.314 & 0.018 & & \\
& $\begin{array}{l}\text { Year of study } \\
\text { First year }\end{array}$ & 145 & 0.37 & 0.483 & 0.040 & 2.017 & $0.05^{*}$ \\
& Post-first year & 290 & 0.27 & 0.444 & 0.026 & &
\end{tabular}

Note: $* p<0.05$

Wawasan Open

University

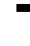


AAOUJ

11,2

132

isolation in the scholarship of learning and research. In a qualitative study investigating cases of student isolation among distance learners, Vighnarajah and Santhiram (2014) found that poor engagement with library services was among the precursors that led students to isolate themselves from the different interactions one would expect from a university learning experience. They further emphasized that distance learners will find it difficult to search for information online particularly if they are unfamiliar with search engine technology and library databases such as EBSCO Host Business Source Complete, Books $24 \times 7$ and eBrary. If not attended to accordingly in the early stages of the learning and research work, students who experience difficulties in effectively searching for information and utilizing the said information could find themselves in a situation of feeling a sense of isolation. This is a situation that should not be taken lightly as it may lead, almost always impulsively, to other relevant learning concerns, such as developing the perceptions of incompetency of learning and the encumbrance of returning to learning, more so of engaging in distance learning.

In light of the aforementioned implication, relevant stakeholders must play their role in guiding students to improve on their information-seeking behaviour. The library plays the most crucial role in this perspective of facilitating distance learners who are not accustomed to effective information-search behaviour and utilization of information, and this should be sustained as a continuous effort in the scholarship of learning and research. This view is in line with Kumar (2013) who emphasizes that the library should organize more programmes and seminars to disseminate awareness among students on effectively collaborating with the library for information search and utilization. Also, it is imperative that these affected groups of distance learners are made aware of this concern to encourage them to seek the necessary guidance from the relevant stakeholders - this is a critical finding that requires attention on part of the library as well as the users (distance learners). For instance, Devi and Dlamini (2014) point out that while 92 per cent of library users are aware of e-resources, 32 per cent of this group finds it difficult to use these e-resources for their immediate needs. Moreover, it is crucial that these measures by the library must be supported by relevant academics and faculties.

It was also interesting to note from the findings that experiencing problems in information search positively correlates with effective utilization of information. In other words, students who experience problems in searching for information are most likely, with 32 per cent of possibility, to experience problems in effectively utilizing the said information mainly with concerns towards integration of information, citation of information and chances of plagiarizing work.

This is a matter of grave concern as pointed out by Head and Eisenberg (as cited in Head, 2013, p. 474): "Eighty percent - eight in ten of the students PIL surveyed in 2010 - reported having overwhelming difficulties with getting started on research assignments and determining the nature and scope of what their instructors required of them". PIL, acronym for Project Information Literacy, was a series of national studies that attempted to investigate the scenario of a college student in an era of digital age. With support from major institutions such as Institute of Museum and Library Services, Cengage Learning, Harvard's Berkman Center for Internet and Society and ProQuest, PIL addressed the findings of surveys and interviews of more than 11,000 students from 57 colleges and universities across the USA.

Hence, it is imperative for students to develop a sense of awareness of this positive correlation between information search and information utilization in an attempt for them to take the necessary measures to seek for guidance from 
the relevant stakeholders. However, it was even more alarming to discover that the services of a librarian were tremendously underutilized: "Across all PIL surveys, students tremendously underutilize librarians. Eight out of ten of the respondents $(80 \%)$ in PIL's 2009 survey reported rarely, if ever, turning to librarians for help with defining topics or searching for sources when working on course-related research assignments" (Head and Eisenberg, 2009, p. 475).

All in all, findings of this study highlighted many important quantitative aspects relevant to information search and information utilization. In an attempt for further improvement, this researchers hope to commence an extended study in the near future aimed at eliciting more profound analysis of larger data set. Among others, this includes determining significant statistical differences between genders and between junior and more senior distance learners in their engagement in information search and information utilization. This extended study also aims to complement these quantitative findings by focussing on qualitative exploration to gain invaluable insight into the cognitive practices of these distance learners when dealing with information search and information utilization - for instance, establishing phenomenological understanding, through means of interviews and observations, of why and how distance learners go about in their information search and information utilization. In this study, the quantitative results did not highlight any particular findings that would satisfactorily explain these phenomena other than identifying the significant differences and/or strength of relationship among variables. Certainly, consolidation of quantitative and qualitative data will provide added value to the aim of this study in profiling information-seeking behaviour of distance learning students in Wawasan Open University.

\section{Conclusion}

Emergence of the internet in the frontiers of distance learning has impacted the delivery of education in more ways than one. This attempt to understand the profiling of information-seeking behaviour among distance learners is no more than a fraction of a larger quality assurance measure to advise and guide students on how to industriously experience distance learning at its best. All in all, results from this study have confirmed that distance learners (at least, in the context of Wawasan Open University) experience critical difficulties in effectively searching for information and utilizing the said information in the scholarship of learning and research. Also, efforts are required from library and relevant stakeholders in guiding distance learners to successfully acquire and manage information in this digital age. This paper reports the preliminary findings and is by no means a comprehensive review on profiling information-seeking behaviour among distance learners. With this in mind and ardour to investigate further into the various facades of profiling information-seeking behaviour, the scope of research has been extended to study a wider population of distance learners in Wawasan Open University.

\section{References}

Alman, S., Tomer, C. and Lincoln, M.L. (2012), Designing Online Learning: A Primer for Librarians, Libraries Unlimited, Oxford.

American Library Association (2008), "Standards for distance learning library services", available at: www.ala.org/acrl/standards/guidelinesdistancelearning (accessed 8 August 2016). 
AAOUJ 11,2

Bawden, D. (2006), "Users, user studies and human information behaviour: a three-decade perspective on Tom Wilson's 'on user studies and information needs"', Journal of Documentation, Vol. 62 No. 6, pp. 671-679.

Brown, C., Murphy, T.J. and Nanny, M. (2003), "Turning techno-savvy into info-savvy: authentically integrating information literacy into the college curriculum", Journal of Academic Librarianship, Vol. 29 No. 6, pp. 386-398.

Byström, K. and Hansen, P. (2005), "Conceptual framework for task in information studies", Journal of the American Society for Information Science and Technology, Vol. 56 No. 10, pp. 1050-1061.

Devi, T.S. and Dlamini, N. (2014), "Information needs and seeking behaviour of agricultural students at the University of Swaziland: a case study", International Journal of Digital Library Services, Vol. 4 No. 2, pp. 1-15.

Distance Learning Section Guidelines Committee (2004), "Guidelines for distance learning library services”, College \& Research Libraries News, Vol. 65 No. 10, pp. 604-611.

Dubicki, E. (2010), "Research behaviour patterns of business students", Reference Services Review, Vol. 38 No. 3, pp. 360-384.

Head, A.J. (2013), "Project information literacy: what can be learned about the informationseeking behaviour of today's college students?", available at: www.ala.org/acrl/sites/ala. org.acrl/files/content/conferences/confsandpreconfs/2013/papers/Head_Project.pdf (accessed 1 August 2016).

Head, A.J. and Eisenberg, M.B. (2009), "Lessons learned: how college students seek information in the digital age - Project Information Literacy", available at: http://projectinfolit.org/pdfs/ PIL_Fall2009_Year1Report_12_2009.pdf (accessed 1 August 2016).

Kadli, J.H. and Kumbar, B.D. (2013), "Library resources, services and information seeking behaviour in changing ICT environment: a literature review", Library Philosophy and Practice (e-Journal), ISSN 1522-0222, Paper 951, available at: http://digitalcommons.unl. edu/libphilprac/ (accessed 21 September 2015).

Krejcie, R.V. and Morgan, D.W. (1970), "Determining sample size for research activities", Educational and Psychological Measurement, Vol. 30 No. 3, pp. 607-610.

Kumar, A. (2013), "Assessing the information need and information seeking behaviour", International Journal of Digital Library Services, Vol. 3 No. 3, pp. 1-12.

Lahlafi, A.E., Rushton, D. and Stretton, E. (2012), "Active and reflective learning initiatives to improve web searching skills of business students”, Journal of Information Literacy, Vol. 6 No. 1, pp. 35-49.

Liu, Z. and Zheng, Y.Y. (2004), "Factors influencing distance-education graduate students' use of information sources: a user study", Journal of Academic Librarianship, Vol. 30 No. 1, pp. 24-35.

Loh, K.H. (2013), "Impact on learners' uncertainty reduction with the infusion of information literacy skills training in problem-based learning environment", Academic Research International, Vol. 4 No. 6, pp. 249-260.

Majka, D. (2001), “The conqueror bookworm”, American Libraries, Vol. 32 No. 6, pp. 60-63.

Shah, C., Capra, R. and Hansen, P. (2014), “Collaborative information seeking (editorial)”, IEEE Computer Magazine, 22-25 March, pp. 22-25, available at: www.computer.org/csdl/mags/ co/2014/03/mco2014030022.pdf (accessed 10 June 2016).

Vighnarajah and Santhiram, R. (2014), "Characterizing key features of student isolation in distance education", unpublished IRI research report, Institute for Research and Innovation, Wawasan Open University. 
Williams, P., Rowlands, I. and Fieldhouse, M. (2008), “The 'Google generation': myths and realities about young people's digital information behaviour", in Nicholas, D. and Rowlands, I. (Eds), Digital Consumers: Reshaping the Information Professions, Chandos, Oxford, pp. 159-192.

Wilson, T.D. (1999), "Models in information behaviour research", Journal of Documentation, Vol. 55 No. 3, pp. 249-270.

Wilson, T.D. (2006), "60 years of the best in information research on user studies and information needs", Journal of Documentation, Vol. 62 No. 6, pp. 658-670.

\section{Corresponding author}

Vighnarajah can be contacted at: iolasus@gmail.com

For instructions on how to order reprints of this article, please visit our website: 